IJMS 17 (1), 203-223 (2010)

\title{
KESAN AMALAN KOMUNIKASI DALAM SISTEM GANJARAN DAN KEADILAN PROSEDUR TERHADAP PRESTASI KERJA
}

\author{
AZMAN ISMAIL \\ DAYANG NAILUL MUNNA ABANG ABDULLAH \\ NORAIDA WAHID \\ Fakulti Sains Kognitif E Pembangunan Manusia \\ Universiti Malaysia Sarawak \\ MOHD NOOR MOHD SHARIFF \\ UUM College of Business \\ Universiti Utara Malaysia
}

\begin{abstract}
ABSTRAK
Kajian ini dilaksanakan untuk mengukur pengaruh persepsi keadilan prosedur dalam perhubungan antara amalan komunikasi dalam sistem ganjaran dan prestasi kerja di sebuah penguasa tempatan berstatus bandar raya di Sarawak, Malaysia. Keputusan analisis regresi berganda hierarki menunjukkan bahawa interaksi antara pengetahuan tentang sistem ganjaran dan keadilan prosedur mempunyai hubungan yang tidak signifikan dengan prestasi kerja, tetapi interaksi antara layanan ketua terdekat dan keadilan prosedur mempunyai hubungan yang signifikan dengan prestasi kerja. Dapatan kajian mengesahkan bahawa keadilan prosedur hanya bertindak sebagai pemboleh ubah penyederhanaan separa dalam model sistem ganjaran dalam organisasi kajian. Justeru itu, implikasi dan limitasi kajian ini, serta cadangan kajian akan datang turut dibincangkan.
\end{abstract}

Kata kunci: Amalan komunikasi dalam sistem ganjaran; keadilan prosedur dan prestasi kerja.

\begin{abstract}
Purpose - This paper seeks to measure the influence of perceived procedural justice; to identify the moderating effects of procedural justice on the knowledge about reward systems; and to identify the moderating effects of procedural justice on the immediate boss treatments toward job performance.
\end{abstract}

Design/Methodology/Approach - The study was dependent on a survey conducted on 92 respondents who had completed the survey questionnaire forms. 
Findings - Outcomes showed that interaction betwen knowledge about reward systems and procedural justice insignificantly correlated with job performance, but interaction between immediate boss treatments and procedural justice significantly correlated with job performance. This result confirmed that procedural justice does act as a partial moderating effect in the reward system model of the organisation sample.

Originality/Value - The paper explores the possible implications and limitations of this study and addresses these to organisations to look at procedural justice as one important element in the compensation system communication.

Keywords - Communication about reward systems; procedural justice and job performance.

Paper type - Research Paper.

\section{Pengenalan}

Ganjaran merupakan konsep pelbagai dimensi dan penafsirannya boleh dibuat mengikut perspektif bahasa dan organisasi. Dari sudut bahasa, ganjaran (reward) bererti pampasan (compensation), saraan (remuneration) atau/dan sistem gaji dan upah. Istilah ini sering diguna pakai secara bertukar ganti dalam organisasi, tetapi merujuk kepada kepada maksud yang sama (Cross, 1995; Milkovich \& Newman, 2008; Rajkumar, 1996). Dari perspektif organisasi, ganjaran merupakan salah satu fungsi pengurusan sumber manusia yang kritikal kerana ia perlu direka dan ditadbir secara teratur bagi memperuntukkan pelbagai jenis ganjaran kepada para pekerja yang menyempurnakan tugas atau perkhidmatan (Anthony, Perrewe \& Kacmar, 1996; Henderson, 2007; Milkovich \& Newman, 2008; Wallace \& Fay, 1988). Majikan biasanya memperuntukkan ganjaran kewangan (contohnya, gaji, bonus dan imbuhan) dan ganjaran bukan kewangan (contohnya, cuti, kemudahan kesihatan, pinjaman, dan faedah persaraan) kepada para pekerja berdasarkan kesepadanan kerja, tempoh perkhidmatan, kekananan atau/dan prestasi seseorang (Maurer, Schulman, Ruwe \& Becherer, 1995; Milkovich \& Newman, 2008; Warner, 1997). Sistem ganjaran yang diurus - dengan efisyien berkemampuan menarik, mengekal dan mendorong para pekerja yang berketrampilan untuk menjayakan wawasan, misi dan matlamat organisasi (Anthony et al., 1996; Balkin \& Gomez-Mejia, 1990; Cascio, 1995).

Tujuan kajian ini dilaksanakan adalah untuk mengukur peranan keadilan prosedur sebagai pemboleh ubah penyederhanaan dalam perhubungan antara amalan komunikasi dalam sistem ganjaran dan prestasi kerja. Sebuah penguasa tempatan berstatus bandar raya di Sarawak telah dipilih sebagai kajian kes. Bagi menjaga nama baik organisasi ini, nama sebenar organisasi telah dirahsiakan.

204 IJMS 17 (1), 203-223 (2010) 


\section{Amalan Komunikasi dalam Sistem Ganjaran}

Dalam konteks sistem pengurusan pampasan, komunikasi merupakan

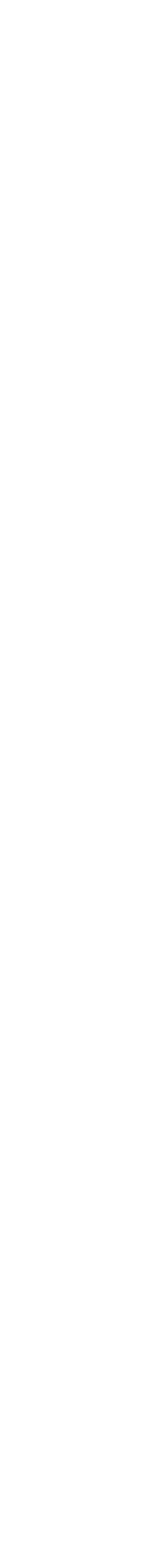
instrumen yang berkesan untuk menyampaikan maklumat tentang sistem ganjaran kepada penerima (pekerja) melalui percakapan, tingkah laku atau/dan tulisan (Fitzgerald, 2000; Hewitt Associates, 1991; Wallace \& Fay, 1988). Dalam mengurus sistem ganjaran, jenis, tahap atau jumlah maklumat yang boleh disampaikan oleh pengurus kepada para pekerja dipengaruhi oleh jenis dasar komunikasi yang diamalkan oleh sesebuah organisasi (Armstrong \& Murlis, 1994; Cascio, 1995; Hewitt Associates, 1991; Wallace \& Fay, 1988).

Bagi organisasi yang mengamalkan dasar komunikasi berahsia (secrecy policy), pertukaran dan perkongsian maklumat mengenai sistem ganjaran hanya berlaku dalam kalangan pihak pengurusan. Penyebaran maklumat mengenai sistem ganjaran kepada para pekerja adalah terhad dan penerangan mengenai perubahan-perubahan dalam dasar dan prosedur memberi pampasan adalah tidak komprehensif. Beberapa kajian yang lepas mendapati pelaksanaan dasar komunikasi berahsia lebih banyak menimbulkan kesan negatif, iaitu para pekerja mudah salah faham, buruk sangka, enggan menghormati pengurusan dan banyak mengkritik terhadap sistem pentadbiran ganjaran (Flannery, Hofrichter \& Platten, 1996; Fitzgerald, 2000; Hewitt Associates, 1991; Lawler, 1981, 1982, 1984, \& 1990).

Dalam organisasi yang mengamalkan dasar komunikasi terbuka (openness policy), para pengurus diberi kuasa budi bicara yang mencukupi untuk menyampaikan maklumat mengenai sistem ganjaran secara terbuka, tepat, jelas dan jujur kepada para pekerja (Fitzgerald, 2000; Leventhal, 1976; Thibault \& Walker, 1978). Amalan komunikasi ini berupaya membantu para pekerja memahami, berpuas hati, menghormati, dan mengiktiraf sistem ganjaran. Seterusnya, persepsi positif ini dapat meningkatkan kredibiliti sistem pentadbiran ganjaran secara keseluruhan (Hewitt Associates, 1991; Lawler, 1990; Miceli \& Lane, 1991).

Kajian awal yang berkaitan dengan bidang pengurusan ganjaran lebih menjurus ke arah perbincangan dan penghuraian konsep-konsep, ciri-ciri, kepentingan dan pengaruh sistem ganjaran terhadap sikap dan tingkah laku pekerja (Cropanzano \& Greenberg, 1997; Mamman \& Sulaiman, 1996; Milkovich \& Newman, 2008; Sweeney \& McFarlin, 1993). Model-model ganjaran awal yang diperkenalkan oleh para sarjana seperti Weber, Fayol dan Taylor adalah berorientasikan pengurusan klasik. Model-model ini kebanyakannya membincangkan tentang jenis, tahap atau/dan jumlah ganjaran serta hubungannya secara langsung dengan sikap dan tingkah laku individu (prestasi atau/dan produktiviti) (Henderson, 2007; Maurer et al., 1995; Robbins \& Coulter, 2005, Snell, 2002).

Model-model ganjaran ini bagaimanapun tidak menghuraikan secara terperinci perhubungan antara elemen-elemen pengurusan ganjaran yang khusus dengan beberapa jenis sikap dan tingkah laku individu 
(Azman, Abdul Fatah \& Mohd Noor, 2007). Sebagai contoh, model-model pengurusan klasik mengabaikan peranan komunikasi sebagai faktor yang mempengaruhi prestasi kerja. Apabila peranan komunikasi diabaikan, ia boleh menyebabkan para pekerja tidak memahami polisi dan prosedur pampasan, membangkitkan prasangka negatif dan mendorong perasaan tidak adil dalam diri para pekerja terhadap sistem pengurusan ganjaran (Fitzgerald, 2000; Flannery et al., 1996; Greenberg, 1996; Lawler, 1981, 1982 \& 1990).

Beberapa kajian tentang sistem pentadbiran ganjaran yang dilaksanakan baru-baru ini mengenal pasti bahawa pengetahuan tentang sistem ganjaran dan layanan ketua terdekat adalah dua amalan komunikasi dalam sistem ganjaran yang mampu mempengaruhi prestasi kerja (Cascio, 1995; Chang \& Chen, 2002). Kebanyakan sarjana seperti Chang dan Chen (2002) dan Jones, Scarpello dan Bergman (1999) mentakrifkan pengetahuan tentang sistem ganjaran sebagai pengetahuan pekerja sama ada mencukupi atau tidak prosedur pembahagian pelbagai bentuk, jenis atau/dan amaun ganjaran yang diamalkan dalam organisasi. Manakala, layanan ketua terdekat dikaitkan dengan cara ketua jabatan atau/dan penyelia berinteraksi dengan para pekerja, seperti memberi penerangan, berbincang dan melayan aduan-aduan yang berkaitan dengan sistem ganjaran di peringkat jabatan (Greenberg, 1987a \& 1987b; 1996 \& 2003; Pettijohn, Pettijohn \& d'Amico, 2001). Melalui sistem komunikasi ini, para pekerja akan dapat memahami dengan jelas bahawa sistem ganjaran mereka diuruskan mengikut polisi dan prosedur yang betul dan ini boleh mendorong mereka meningkatkan prestasi kerja.

Pengamatan yang lebih mendalam terhadap perhubungan tersebut mendapati kesan amalan komunikasi dalam sistem ganjaran terhadap prestasi kerja adalah tidak konsisten apabila persepsi keadilan prosedur hadir dalam organisasi (Chang \& Chen, 2002; Guthrie, 2000; Zenger, 1992). Dalam konteks pengurusan sistem ganjaran, para pekerja yang mengetahui sistem ganjaran diurus mengikut prosedur yang betul dan menerima layanan dengan baik yang diberikan oleh ketua terdekat akan dapat membangkitkan perasaan adil dalam diri mereka terhadap prosedur pembahagian ganjaran. Seterusnya, perasaan adil ini boleh mendorong para pekerja menambahbaik prestasi kerja (Cascio, 1995; Chang \& Chen, 2002). Sungguhpun perhubungan ini dibincangkan dalam kajian lepas, namun sedikit sahaja diketahui tentang peranan keadilan prosedur sebagai pemboleh ubah penyederhana dalam model pengurusan ganjaran (Greenberg, 2003; Pettijohn et al., 2001; Robbins \& Coulter, 2005). Oleh itu, kajian yang lebih mendalam tentang sifat perhubungan ini adalah imperatif.

\section{Kajian Literatur}

Teori keadilan prosedur adalah satu cabang penting teori keadilan organisasi yang dibina berdasarkan teori perbandingan sosial (Adams, 1963 \& 1965; Cohen-Charash \& Spector, 2001; Moorman, 1991). Teori keadilan prosedur seringkali ditakrifkan sebagai persepsi keadilan terhadap proses dan sistem 


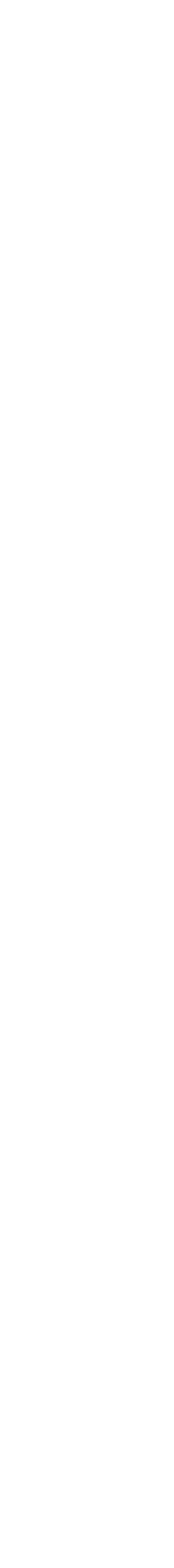

membuat keputusan yang diamalkan dalam organisasi (Cropanzano, Byrne, Bobocel, \& Rupp, 2001; Cropanzano \& Greenberg, 1997, Greenberg, 1987a \& 1987b). Dalam konteks pengurusan pampasan, teori keadilan prosedur menegaskan bahawa persepsi keadilan terhadap sistem dan proses membahagi-bahagikan pelbagai jenis, tahap atau/dan amaun ganjaran adalah faktor penentu yang mendorong peningkatan sikap dan gelagat pekerja yang positif, terutamanya prestasi kerja (Folger \& Konovsky, 1989; Konovsky \& Pugh, 1994).

Dakwaan teori keadilan organisasi ini mendapat sokongan daripada kajian literatur pampasan yang kebanyakannya diterbitkan di negara Barat. Sebagai contoh, Cooper, Dyck dan Frohlich (1992) mengkaji keberkesanan sistem faedah kerja dan mendapati bahawa kefahaman para pekerja terhadap prosedur pembahagian ganjaran telah membangkitkan perasaan adil dalam diri pekerja terhadap sistem faedah kerja, dan ini boleh mendorong meningkatkan daya pengeluaran kerja. Selain itu, Schaubroeck, May dan Brown (1994) mengkaji tentang polisi pampasan dan mendapati bahawa keupayaan ketua terdekat memberi penerangan yang jelas dan telus tentang polisi pembahagian ganjaran kepada para pekerja telah membangkitkan perasaan keadilan prosedur dalam diri pekerja, ini seterusnya boleh mempengaruhi prestasi kerja. Literatur sistem ganjaran di atas telah dijadikan panduan bagi membina kerangka konseptual kajian ini seperti yang ditunjukkan dalam Rajah 1.

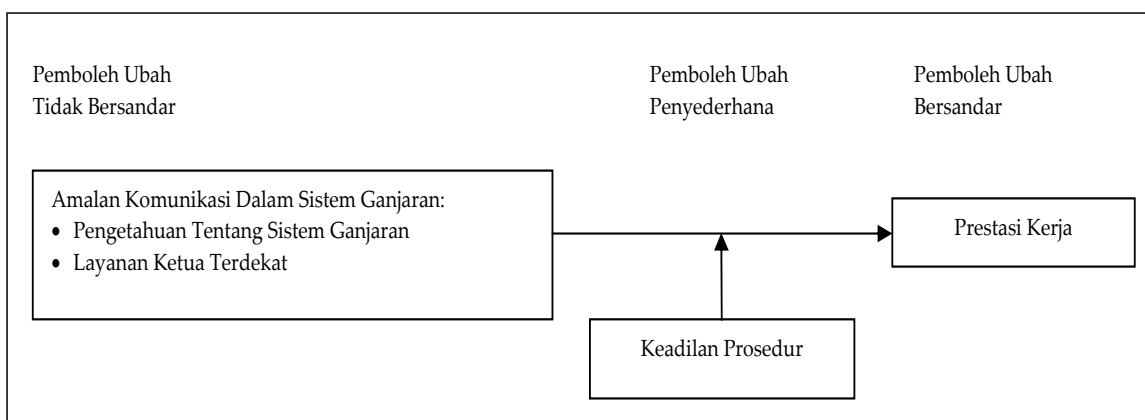

Rajah 1. Keadilan prosedur menyederhana kesan amalan komunikasi dalam sistem ganjaran ke atas prestasi kerja.

Kerangka konseptual ini memberi panduan kepada para penyelidik untuk mencadang dan menguji hipotesis-hipotesis berikut:

H1: Keadilan prosedur menyederhana kesan pengetahuan tentang sistem ganjaran terhadap prestasi kerja.

H2: Keadilan prosedur menyederhana kesan layanan ketua terdekat terhadap prestasi kerja.

IJMS 17 (1), 203-223 (2010) 


\section{Metodologi}

Kajian ini menggunakan kaedah keratan rentas yang membenarkan pengkaji mengumpul data melalui kajian literatur, temuduga secara mendalam, kajian rintis dan pengedaran borang soal selidik. Kaedah ini berupaya membantu pengumpulan data secara tepat, mengelakkan pilih kasih, relevan dengan keperluan sesuatu kajian dan boleh dipercayai untuk mengukur persepsi responden terhadap pemboleh ubah-pemboleh ubah kajian (Leedy \& Ormrod, 2005, Sekaran, 2000).

- Temuduga terperinci telah dilaksanakan pada peringkat awal kajian bagi memahami secara mendalam tentang konsep, peristiwa dan fenomena dalam organisasi kajian (Van Maanen, 1983). Sesi temu duga ini telah dijalankan dengan kakitangan daripada Bahagian Sumber Manusia, iaitu seorang pegawai sumber manusia, seorang pembantu pegawai dan seorang pekerja sokongan. Mereka dipilih berdasarkan teknik pensampelan purposif, iaitu individu tersebut mempunyai pengalaman kerja lebih daripada 10 tahun dalam bidang pengurusan dan terlibat secara langsung dalam pentadbiran sistem ganjaran. Tujuan temuduga ini dilaksanakan untuk memahami dengan lebih jelas tentang amalan komunikasi dalam pengurusan sistem ganjaran, ciri-ciri keadilan prosedur dan ciri-ciri prestasi kerja, serta perhubungan antara pemboleh ubah tersebut di organisasi kajian. Maklumat yang diperoleh daripada temuduga ini telah digunakan untuk membentuk kandungan dan format borang soal selidik bagi kajian rintis. Kajian rintis telah dijalankan melalui perbincangan dengan tiga orang pekerja sokongan yang mempunyai pengalaman kerja lebih daripada 10 tahun di organisasi kajian. Maklum balas yang diterima daripada temuduga ini telah digunakan untuk menambah baik kandungan dan format borang soal selidik bagi kajian sebenar. Cara ini dipercayai boleh mengumpul data yang tepat, kurang bias dan lebih berkualiti (Leedy \& Ormrod, 2005; Sekaran, 2000).

Kaedah terjemahan balik (back translation) telah digunakan untuk menterjemah borang soal selidik dalam dua bahasa iaitu bahasa Malaysia dan Inggeris bagi memastikan kesahan dan kebolehpercayaan instrumen kajian (Sekaran, 2000; Wright, 1996). Borang soal selidik merupakan instrumen pengumpulan data utama bagi kajian ini. Borang soal selidik

- kajian ini mengandungi empat seksyen. Pertama, soalan-soalan mengenai demografi responden. Kedua, amalan komunikasi dalam sistem ganjaran diukur menggunakan 11 soalan yang telah diubah suai daripada literatur pengurusan ganjaran (Heneman \& Schwab, 1985; Martin \& Lee, 1992; Williams, 1995). Item yang digunakan untuk mengukur pengetahuan tentang sistem ganjaran ialah (1) saluran menyelesaikan aduan ketidaksamarataan bayaran gaji, (2) polisi larangan membincangkan isu ganjaran, dan (3) polisi larangan membincangkan isu kenaikan pangkat. Item yang digunakan untuk mengukur layanan ketua terdekat ialah (1) mewakili kepentingan pekerja dalam soal ganjaran, (2) menyokong aduan yang berkaitan dengan gaji, (3) bersikap terbuka dan berterus-terang tentang kenaikan gaji, (4) 


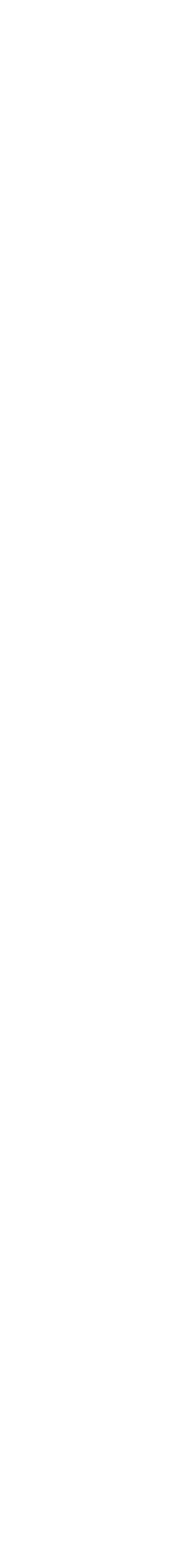

bersikap jujur dan beretika ketika berurusan dengan isu bayaran gaji, (5) mengguna ukuran yang sama ketika membuat keputusan berkenaan gaji, (6) menerangkan perubahan dalam prosedur dan polisi gaji, (7) menerangkan perubahan dalam prosedur dan polisi faedah kerja, dan (8) memahami dengan jelas berkenaan sistem ganjaran yang dilaksanakan di organisasi.

Ketiga, keadilan prosedur diukur menggunakan lima item yang diubah suai daripada skala pengukuran yang dibina oleh Moorman (1991). Item yang digunakan untuk mengukur pemboleh ubah ini ialah (1) prosedur mengumpul maklumat bagi membuat keputusan berkenaan ganjaran, (2) prosedur merayu atau mencabar keputusan kenaikan gaji, (3) prosedur merayu atau mencabar keputusan kenaikan pangkat, (4) prosedur merayu atau mencabar keputusan berkaitan faedah kerja, dan (5) prosedur yang direka untuk membenarkan staf memohon penjelasan atau maklumat tambahan berkenaan keputusan ganjaran. Keempat, prestasi kerja diukur menggunakan sembilan item yang diambil daripada skala pengukuran yang dibina oleh Lawler dan Hall (1970). Item yang digunakan untuk mengukur pemboleh ubah ini ialah (1) ketidakhadiran kerja dengan sebab munasabah, (2) bersemangat menjalankan tugas tanpa kehadiran penyelia, (3) tidak pernah membuat kerja-kerja lain yang tidak berkaitan dengan tugas, (4) tidak membawa masalah yang tidak berkaitan dengan tugas ke tempat kerja, (5) tidak lengah-lengahkan kerja, (6) tidak kisah bekerja lebih masa tanpa memikirkan kesetimpalan gaji, (7) rakan sekerja sering menjadikan saya sebagai tempat rujukan, (8) tidak pernah melanggar peraturan yang ditetapkan organisasi, dan (9) keupayaan menyiapkan tugas dalam tempoh yang ditetapkan.

Kesemua item diukur menggunakan skala tujuh pilihan jawapan yang bermula daripada "sangat tidak setuju/sangat tidak puas hati" (1) kepada "sangat setuju/sangat puas hati" (7). Data demografi responden hanya digunakan sebagai pemboleh ubah kawalan kerana kajian ini memfokuskan kepada sikap pekerja.

Jumlah pekerja yang berkhidmat di organisasi kajian ialah 1007 pekerja. Dengan mengambil kira halangan peraturan organisasi ini, pengkaji menggunakan kaedah persampelan mudah bagi mengedar 200 borang soal selidik kepada pekerja di organisasi kajian. Daripada jumlah tersebut, sebanyak 92 borang soal selidik sahaja yang diisi dengan lengkap. Responden kajian ini telah menjawab borang soal selidik berdasarkan kerelaan dan persetujuan masing-masing. Jumlah sampel kajian ini melebihi jumlah sampel minimum iaitu 30 orang dan ini membolehkan hipotesis-hipotesis kajian diuji menggunakan analisis statistik inferensi (Leedy \& Ormrod, 2005; Sekaran, 2000). Pakej Statistik untuk Sains Sosial (SPSS) versi 14.0 telah digunakan untuk mengenal pasti profil sampel kajian, menghasilkan statistik deskriptif, menilai psikometrik data soal selidik kajian, menganalisis korelasi Pearson, dan seterusnya menguji hipotesis kajian.

IJMS 17 (1), 203-223 (2010) 


\section{Dapatan Kajian}

Dari segi profil sampel kajian, Jadual 1 menunjukkan ciri-ciri responden dan peratusan kumpulan terbesar adalah 53.3\% lelaki, 53.3\% berumur antara 36 hingga 45 tahun, $68.5 \%$ berpendidikan SPM, $72.8 \%$ adalah kumpulan bukan teknikal, 38\% telah berkhidmat antara 10 hingga 15 tahun, $71.7 \%$ responden berbangsa Melayu dan 45.7\% menerima gaji di antara RM1501 - RM2000 sebulan.

Jadual 1

Profil Sampel Kajian

\begin{tabular}{|c|c|c|c|}
\hline Ciri-ciri Umum Responden & Ciri-ciri Khusus Responden & Bilangan & Peratusan \\
\hline Jantina & $\begin{array}{l}\text { Lelaki } \\
\text { Perempuan }\end{array}$ & $\begin{array}{l}49 \\
43\end{array}$ & $\begin{array}{l}53.3 \\
46.7\end{array}$ \\
\hline Umur & $\begin{array}{l}25 \text { tahun dan ke bawah } \\
26-35 \text { tahun } \\
36-45 \text { tahun } \\
46-50 \text { tahun } \\
\text { Lebih daripada } 50 \text { tahun }\end{array}$ & $\begin{array}{r}3 \\
34 \\
49 \\
5 \\
1\end{array}$ & $\begin{array}{r}3.3 \\
37.0 \\
53.3 \\
5.4 \\
1.1\end{array}$ \\
\hline Tahap Pendidikan & $\begin{array}{l}\text { PMR/SRP } \\
\text { SPM/SAP } \\
\text { STPM } \\
\text { Diploma } \\
\text { Ijazah } \\
\text { Lain-lain }\end{array}$ & $\begin{array}{r}6 \\
63 \\
3 \\
5 \\
7 \\
8\end{array}$ & $\begin{array}{r}6.5 \\
68.5 \\
3.3 \\
5.4 \\
7.6 \\
8.7\end{array}$ \\
\hline Jawatan & $\begin{array}{l}\text { Kumpulan Teknikal } \\
\text { Kumpulan Bukan Teknikal }\end{array}$ & $\begin{array}{l}25 \\
67\end{array}$ & $\begin{array}{l}27.2 \\
72.8\end{array}$ \\
\hline Tempoh Perkhidmatan & $\begin{array}{l}\text { Kurang daripada } 1 \text { tahun } \\
1-5 \text { tahun } \\
6-10 \text { tahun } \\
11-15 \text { tahun } \\
\text { Lebih daripada } 15 \text { tahun }\end{array}$ & $\begin{array}{r}2 \\
19 \\
8 \\
35 \\
28\end{array}$ & $\begin{array}{r}2.2 \\
20.7 \\
8.7 \\
38.0 \\
30.4\end{array}$ \\
\hline Bangsa & $\begin{array}{l}\text { Melayu } \\
\text { Cina } \\
\text { Iban } \\
\text { Lain-lain }\end{array}$ & $\begin{array}{r}66 \\
8 \\
5 \\
14\end{array}$ & $\begin{array}{r}71.7 \\
8.7 \\
5.4 \\
14.1\end{array}$ \\
\hline Gaji & $\begin{array}{l}\text { Kurang daripada RM1000 } \\
\text { RM1001 - RM1500 } \\
\text { RM1501 - RM2000 } \\
\text { RM2001 - RM2500 } \\
\text { RM2501 - RM3000 } \\
\text { Lebih daripada RM3000 }\end{array}$ & $\begin{array}{r}7 \\
27 \\
42 \\
10 \\
4 \\
2\end{array}$ & $\begin{array}{r}7.6 \\
29.3 \\
45.7 \\
10.9 \\
4.3 \\
2.2\end{array}$ \\
\hline
\end{tabular}

Nota. $\quad$ PMR/SRP = Peperiksaan Menengah Rendah/Sijil Rendah Pelajaran n=92.

SPM/SAP = Sijil Pelajaran Malaysia/Sijil Am Pelajaran STPM = Sijil Tinggi Persekolahan Malaysia.

210 IJMS 17 (1), 203-223 (2010) 


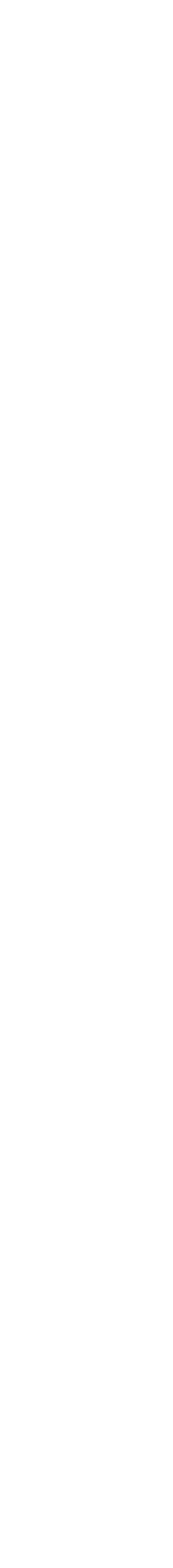

Jadual 2 menunjukan keputusan ujian psikometrik bagi skala pengukuran. Ujian Kaiser-Meyer-Olkin (KMO) perlu dilakukan terlebih dahulu bagi mengenal pasti kecukupan saiz sampel kajian dan diikuti oleh analisis faktor melalui teknik direct oblimin bagi memeriksa tahap kesahan item dalam borang soal selidik (Hair, Anderson, Tatham, \& Black, 1998; Nunally \& Bernstein, 1994). Keputusan ujian statistik ini telah menunjukkan bahawa item-item dalam analisis mencapai nilai 0.6 dan lebih, serta Bartlett's test of spherecity adalah signifikan, bererti saiz sampel kajian ini diyakini mencukupi untuk dilakukan ujian kesahan dan kebolehpercayaan bagi skala pengukuran. Kedua, item-item yang mewakili setiap pemboleh ubah kajian mempunyai nilai muatan faktor (factor loading) lebih besar daripada 0.40, bererti item-item kajian ini mencapai tahap kesahan yang tinggi. Ketiga, Seterusnya, setiap pemboleh ubah kajian mempunyai nilai eigen lebih besar dari nilai 1, bermaksud pemboleh ubah kajian ini mencapai tahap kesahan yang tinggi. Akhir sekali, setiap pemboleh ubah kajian mempunyai nilai alpha Cronbach lebih besar daripada 0.70, menunjukkan bahawa pemboleh ubah kajian mempunyai kebolehpercayaan yang tinggi. Keputusan statistik ini mengesahkan bahawa skala pengukuran kajian ini mempunyai tahap kesahan dan kebolehpercayaan yang tinggi seperti mana ditunjukkan dalam Jadual 2.

Jadual 3 menunjukkan keputusan ujian statistik asas dan korelasi Pearson. Nilai min bagi setiap pemboleh ubah berada antara 4.7 hingga 5.5 , bererti tahap pengetahuan tentang sistem ganjaran, layanan ketua terdekat, prestasi kerja dan keadilan prosedur berada antara tahap tinggi (4) dan sangat tinggi (7). Pekali korelasi antara pemboleh ubah tidak bersandar (pengetahuan tentang sistem ganjaran dan layanan ketua terdekat), pemboleh ubah penyederhana (keadilan prosedur) dan pemboleh ubah bersandar (prestasi kerja) berada pada nilai yang rendah daripada 0.90 , menunjukkan bahawa data kajian ini adalah bebas daripada masalah kolineariti (Hair et al., 1998; Sekaran, 2000).

Kesan pemboleh ubah penyederhanaan (moderating effects) menerangkan bahawa kesan pemboleh ubah tidak bersandar ke atas pemboleh ubah bersandar akan menjadi tidak konsisten apabila pemboleh ubah lain hadir dalam perhubungan tersebut (Jaccard, Turrisi \& Wan, 1990). Kebanyakan sarjana berpendapat bahawa pakej statistik yang menggunakan model persamaan struktur (structural equation modelling) dan pakej statistik yang menggunakan analisis regresi hierarki mempunyai perbezaan dari segi pengendalian data (data treatment), tetapi kedua-dua teknik ini adalah sama penting dan sesuai untuk digunakan bagi mengukur kesan pemboleh ubah penyederhana dalam kerangka teori kajian (Bryne, 1998; Hair et al., 1998; Jaccard \& Wan, 1996). Beberapa sarjana mencadangkan bahawa analisis regresi hierarki lebih sesuai untuk menguji model penyederhanaan

IJMS 17 (1), 203-223 (2010) 
(moderating model) kerana beberapa faktor: pertama, pemboleh ubah demografi responden dapat dimasukkan dalam Model 1 sebagai pemboleh ubah kawalan dan sejauh mana sumbangannya dapat ditentukan melalui perbandingan dengan Model 2 (pemboleh ubah tidak bersandar) dan Model 3 (pemboleh ubah penyederhana) dalam satu jadual analisis regresi hierarki. Dalam statistik, pemboleh ubah kawalan dikenali juga sebagai pemboleh ubah penganggu (counfounding variable) yang perlu dikawal bagi menghasilkan keputusan pengujian hipotesis yang lebih tepat. Sebagai contoh, kemasukan dan pengecualian beberapa atau kesemua pemboleh ubah kawalan dalam Model 1 akan mempengaruhi darjah keteguhan perhubungan di antara pemboleh ubah atau/dan keputusan pengujian hipotesis. Sekiranya kemasukan dan pengecualian pemboleh ubah kawalan dalam analisis regresi hierarki mewujudkan perbezaan atau sebaliknya, ini akan dapat membantu pengkaji membuat penafsiran dan kesimpulan yang lebih tepat (Aiken, West \& Reno, 1990; Kleinbaum, Kupper \& Muller, 1988).

Kedua, mengesan kehadiran kesan pemboleh ubah penyederhana melalui perbandingan antara Model 2 (pemboleh ubah tidak bersandar) dan Model 3 (pemboleh ubah penyederhana) dalam satu jadual analisis regresi hierarki. Sebagai contoh, kehadiran kesan pemboleh ubah penyederhana dapat diperhati dengan jelas apabila tahap kesignifikanan atau darjah keteguhan perhubungan antara pemboleh ubah tidak bersandar dan pemboleh ubah bersandar mengalami perubahan selepas kemasukan pemboleh ubah penyederhana dalam Model 3. Perbezaan dari segi nilai beta standard (ß) dan nilai korelasi berganda kuasa dua $\left(R^{2}\right)$ dalam Model 2 (pemboleh ubah tidak bersandar) dan Model 3 (pemboleh ubah penyederhana) akan memudahkan pengkaji mengenal kesan pemboleh ubah penyederhana dan seterusnya membuat penilaian dan ramalan yang lebih tepat (Cohen \& Cohen, 1983; Jaccard et al., 1990).

Menurut Cohen dan Cohen (1983), analisis regresi hierarki mampu menunjukkan kehadiran kesan pemboleh ubah penyederhana dalam kerangka konseptual apabila interaksi antara pembolehubah tidak bersandar dan pemboleh ubah penyederhana mempunyai hubungan yang signifikan dengan pemboleh ubah bersandar (contohnya, pada tahap siginifikan $\mathrm{p}=<0.05 ; \mathrm{p}=<0.01 ; \mathrm{p}=<0.001)$. Sebaliknya, jika nilai korelasi berganda kuasa dua $\left(\mathrm{R}^{2}\right)$ bagi pemboleh ubah penyederhana lebih tinggi daripada nilai korelasi berganda kuasa dua $\left(\mathrm{R}^{2}\right)$ bagi pemboleh ubah tidak bersandar, ini bererti pemboleh ubah penyederhana mempengaruhi darjah kekuatan perhubungan antara pemboleh ubah tidak bersandar dan pemboleh ubah bersandar dalam sampel data (Cohen \& Cohen, 1983; Jaccard et al., 1990).

Jadual 4 menunjukkan keputusan ujian analisis regresi berganda hierarki bagi keadilan prosedur sebagai pemboleh ubah penyederhana dan prestasi kerja sebagai pemboleh ubah bersandar.

212 IJMS 17 (1), 203-223 (2010) 

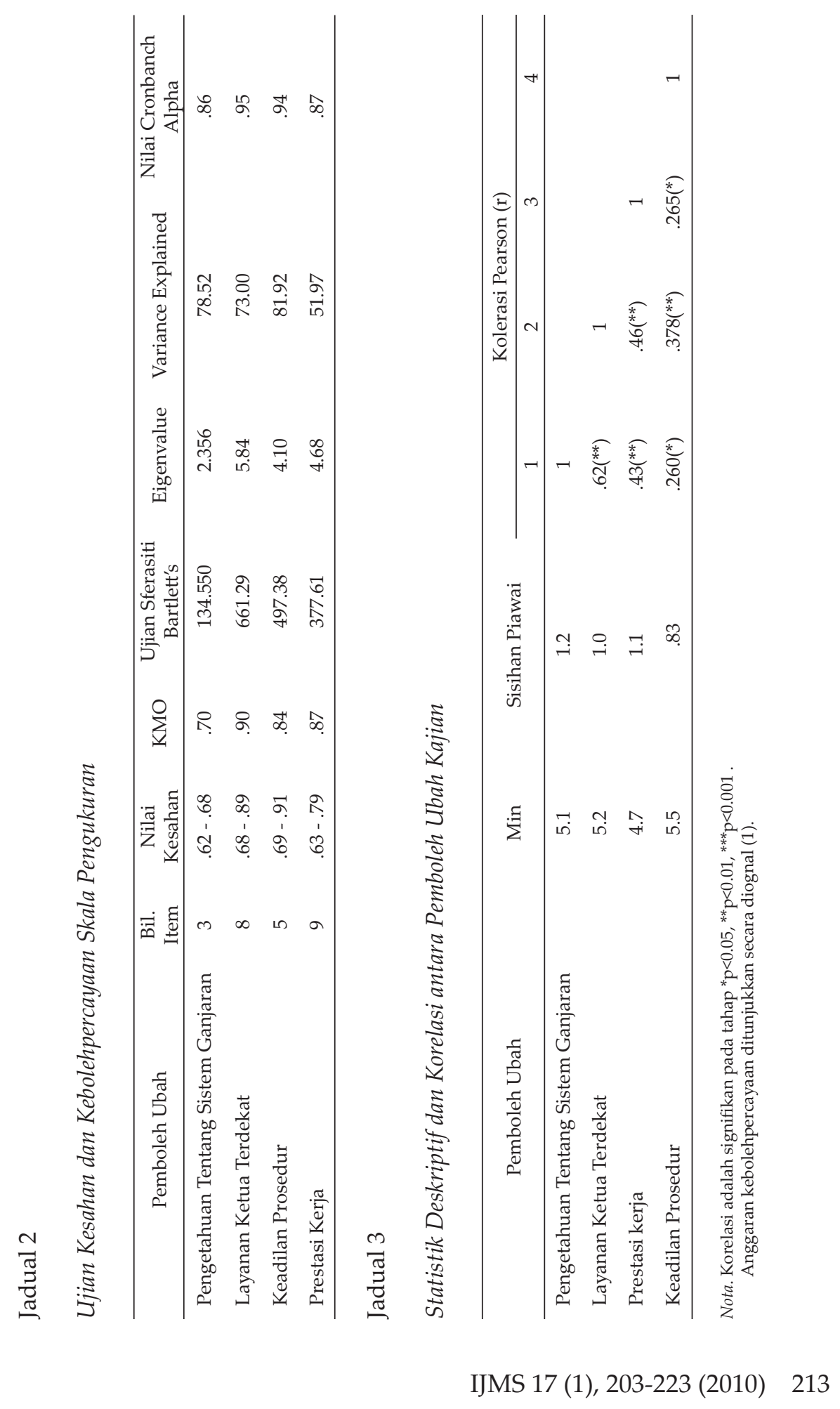
Jadual 4

Keputusan Ujian Analisis Regresi Berganda Hierarki

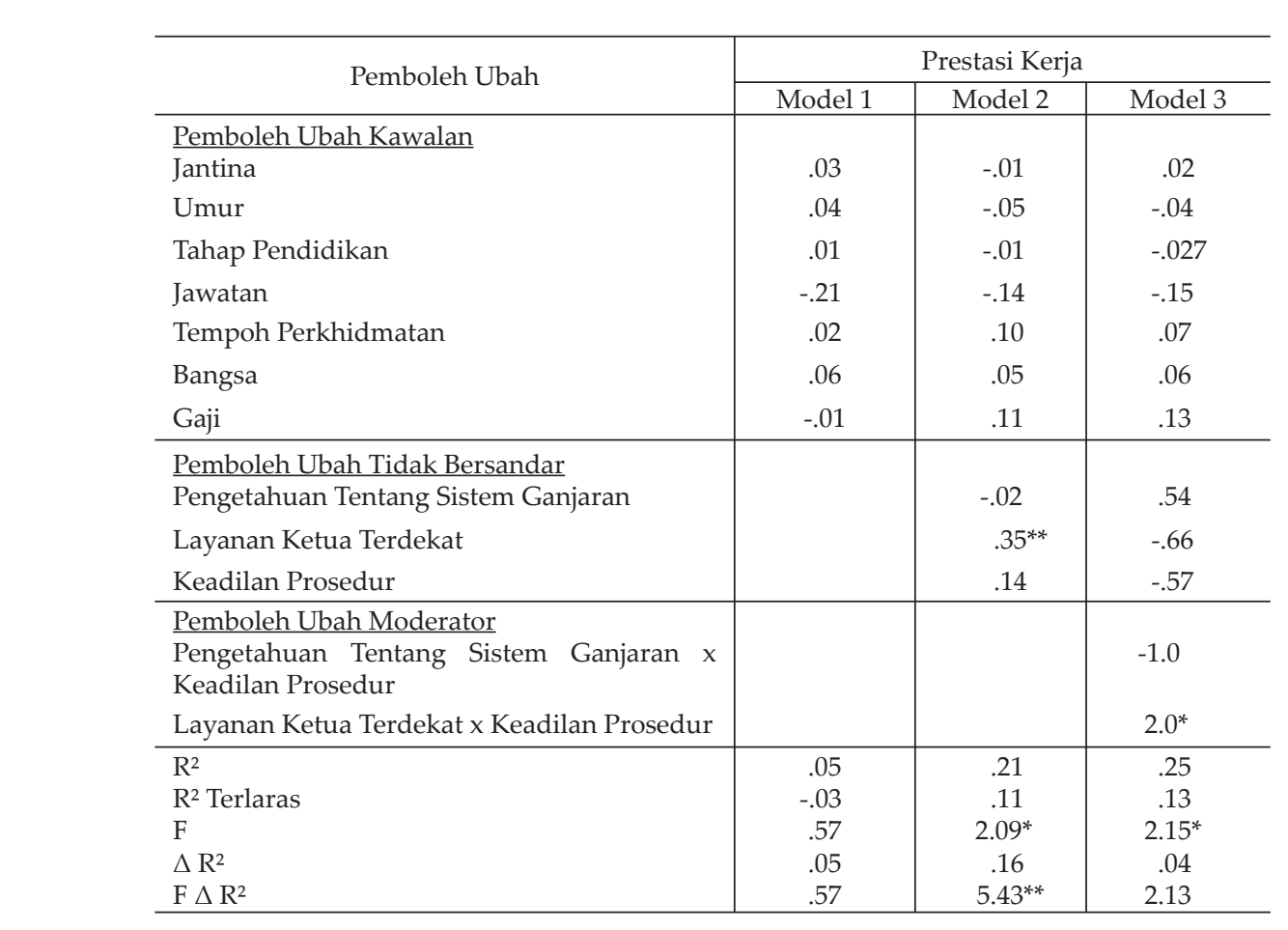

Nota. ${ }^{*} \mathrm{p}<0.05 ;{ }^{* *} \mathrm{p}<0.01 ;{ }^{* * *} \mathrm{p}<0.001$.

Jadual regresi hierarki di atas menunjukkan tiga jenis model: Model 1 merujuk kepada ciri-ciri demografi responden kajian sebagai pemboleh ubah kawalan. Model 2 adalah amalan komunikasi dalam sistem ganjaran (pengetahuan tentang sistem ganjaran dan layanan ketua terdekat) dan keadilan prosedur sebagai pemboleh ubah tidak bersandar. Model 3 menerangkan interaksi di antara amalan komunikasi dalam sistem ganjaran dan keadilan prosedur sebagai pemboleh ubah penyederhana. Akhir sekali, prestasi kerja digunakan sebagai pemboleh ubah bersandar dalam kajian ini.

Keputusan analisis regresi hierarki menerangkan tiga model tersebut. Model 1 menunjukkan bahawa ciri-ciri demografi responden (jantina, umur, tahap pendidikan, jawatan, tempoh perkhidmatan, bangsa dan gaji) tidak mempunyai hubungan yang signifikan dengan prestasi kerja, ini bererti faktor demografi tidak mempengaruhi prestasi kerja.

Model 2 memaparkan bahawa amalan komunikasi dalam sistem ganjaran, iaitu pengetahuan tentang sistem ganjaran mempunyai hubungan yang

214 IJMS 17 (1), 203-223 (2010) 


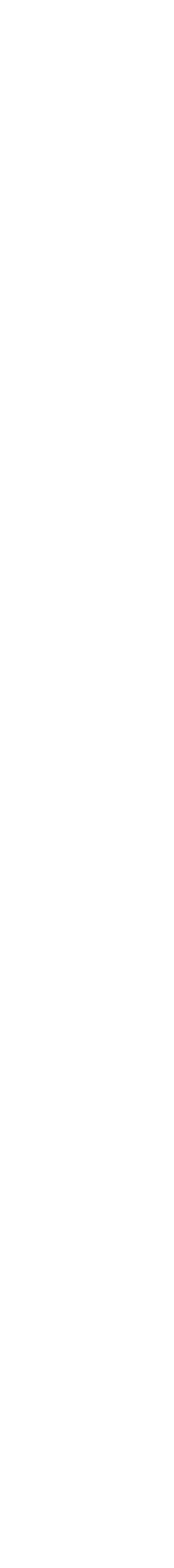

tidak signifikan dengan prestasi kerja ( $\beta=-.02, p>0.05)$, manakala layanan ketua terdekat mempunyai hubungan yang signifikan dengan prestasi kerja $(\beta=.35, p>0.01)$. Ini bererti pengetahuan tentang sistem ganjaran adalah faktor yang tidak mempengaruhi prestasi kerja dan layanan ketua terdekat adalah peramal yang penting kepada prestasi kerja. Selain itu, keadilan prosedur mempunyai hubungan yang tidak signifikan dengan prestasi kerja $(\beta=.14$, $\mathrm{p}>0.05)$, bererti ia bukanlah faktor yang mempengaruhi prestasi kerja. Dari segi kekuatan pengaruh dalam sampel kajian, kemasukan pemboleh ubah ini dalam Model 2 telah menyumbang sebanyak 21\% perubahan varian dalam pemboleh ubah bersandar.

Model 3 mengketengahkan bahawa interaksi antara amalan komunikasi dalam sistem ganjaran dan prestasi kerja. Secara khusus, interaksi antara pengetahuan tentang sistem ganjaran dan keadilan prosedur mempunyai hubungan yang tidak signifikan dengan prestasi kerja $(\beta=-.1 .0, p>0.05)$, bermaksud $\mathrm{H} 1$ adalah ditolak. Manakala, interaksi di antara layanan ketua terdekat dan keadilan prosedur mempunyai hubungan yang signifikan dengan prestasi kerja $(\beta=2.0, \mathrm{p}>0.05)$, bermaksud $\mathrm{H} 2$ adalah diterima.

Dapatan ujian hipotesis tersebut menerangkan bahawa sebelum kemasukan keadilan prosedur sebagai pemboleh ubah penyederhanaan ke dalam Model 2 , perhubungan antara pengetahuan tentang sistem ganjaran dan prestasi kerja adalah tidak signifikan $(\beta=.35, \mathrm{p}>0.01)$, dan perhubungan antara layanan ketua terdekat dan prestasi kerja adalah signifikan $(\beta=.35$, $p>0.01)$. Setelah kemasukan keadilan prosedur sebagai pemboleh ubah penyederhanaan ke dalam Model 3, perhubungan yang tidak signifikan antara pengetahuan tentang sistem ganjaran dan prestasi kerja $(\beta=.35, p>0.01)$ tidak bertukar kepada signifikan $(\beta=.54, p>0.05)$, dan perhubungan yang signifikan antara layanan ketua terdekat dan prestasi kerja $(\beta=.35, \mathrm{p}>0.01)$ telah bertukar kepada tidak signifikan $(\beta=-.57, p>0.05)$. Dari segi kekuatan pengaruh dalam sampel kajian, kemasukan pemboleh ubah penyederhanaan dalam Model 3 telah menyumbang sebanyak $25 \%$ perubahan varian dalam pemboleh ubah bersandar. Keadaan ini menunjukan bahawa kemasukan keadilan prosedur dalam analisis kajian telah menyederhanakan kesan amalan komunikasi dalam sistem ganjaran terhadap prestasi kerja di organisasi kajian.

\section{Perbincangan}

Keputusan kajian ini menunjukkan bahawa keadilan prosedur hanya bertindak sebagai pemboleh ubah penyederhanaan separa antara komunikasi sistem ganjaran dengan prestasi kerja. Dalam organisasi kajian, maklumat berkenaan gaji pokok, faedah-faedah seperti elaun, cuti dan notis perletakan jawatan telah dinyatakan dalam surat tawaran bekerja. Pekerja yang mempunyai keraguan tentang isu berkaitan pampasan seperti ganjaran

IJMS 17 (1), 203-223 (2010) 
berasaskan penilaian prestasi dan kenaikan gaji dibenarkan mengutara permasalahan mereka secara terus kepada ketua terdekat seperti penyelia masing-masing ataupun merujuk kepada pegawai sumber manusia di organisasi. Kebanyakan pekerja berasa layanan yang diberikan oleh ketua terdekat sangat memuaskan, ini telah membangkitkan perasaan keadilan dalam diri pekerja terhadap prosedur pembahagian ganjaran. Seterusnya, keadaan ini boleh mendorong meningkatkan prestasi kerja di organisasi kajian.

Di samping itu, kebanyakan pekerja merasakan bahawa amalan komunikasi yang terbuka dapat meningkatkan tahap pengetahuan terhadap sistem ganjaran, ini telah meningkatkan perasaan adil dalam diri pekerja terhadap prosedur pembahagian ganjaran. Sungguhpun perasaan adil terhadap prosedur pembahagian ganjaran adalah tinggi, keadaan ini tidak mampu mendorong meningkatkan prestasi kerja di organisasi kajian. Pengamatan yang mendalam terhadap maklumat temuduga terperinci menunjukkan - bahawa keadilan prosedur tidak berupaya bertindak sebagai pemboleh ubah penyederhanaan antara pengetahuan tentang sistem ganjaran dan prestasi kerja mungkin disebabkan oleh beberapa faktor luaran. Pertama, pembahagian ganjaran kerja bergantung kepada jumlah hasil pungutan cukai tahunan pihak berkuasa tempatan. Keadaan ini akan menyebabkan jumlah atau/dan tahap ganjaran kerja yang diterima oleh para pekerja adalah tidak konsisten dan boleh mengganggu kecukupan pekerja untuk mengurus perbelanjaan harian. Apabila keadaan ini wujud, ianya boleh meningkatkan perasaan ketidakpuasan di tempat kerja. Kedua, dasar kenaikan pangkat lebih mengutamakan tempoh perkhidmatan dan kekananan. Kriteria kenaikan pangkat ini membangkitkan perasaan kurang puas hati terutamanya dalam kalangan pekerja yang berprestasi tinggi kerana peluang kenaikan pangkat harus diberi mengikut giliran kekananan. Sekiranya cadangan ini diabaikan, ianya akan membangkitkan perasaan tidak adil terhadap prosedur pembahagian ganjaran dan seterusnya boleh meningkatkan sikap dan tingkah laku negatif di tempat kerja.

\section{Implikasi}

Implikasi kajian ini boleh dibahagikan kepada tiga aspek iaitu: teori, kaedah penyelidikan dan pengamal. Dari segi sumbangan kepada teori, kajian ini telah menunjukkan dua penemuan yang penting iaitu: pertama, keadilan prosedur tidak berjaya menyederhanakan kesan pengetahuan tentang sistem ganjaran terhadap prestasi kerja di organisasi kajian. Dapatan ini tidak konsisten dengan kajian yang dilakukan oleh Fitzgerald (2000), Leventhal (1976), dan Thibault dan Walker (1978).

216 IJMS 17 (1), 203-223 (2010) 


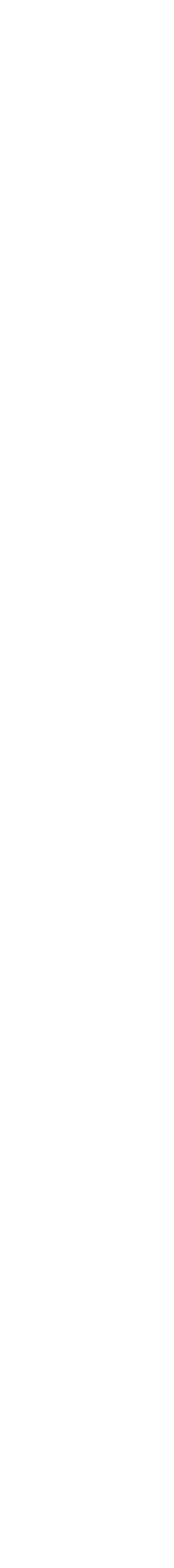

Kedua, keadilan prosedur berjaya menyederhanakan kesan layanan ketua terdekat terhadap prestasi kerja di organisasi kajian. Dapatan ini konsisten dengan kajian yang dilakukan oleh Lind dan Tyler (1988), Robbins, Summer, Miller dan Hendrix (2000), dan Schaubroeck, May dan Brown (1994). Dari perspektif kaedah penyelidikan, data kajian yang telah dikumpul melalui kajian literatur, temuduga terperinci, kajian rintis dan borang soal selidik berkemampuan meningkatkan tahap kesahan dan kebolehpercayaan skala pengukuran, seterusnya ini dapat membantu menghasilkan dapatan kajian yang tepat dan boleh dipercayai.

Dapatan kajian ini juga berguna untuk dijadikan panduan kepada pengamal bagi menambahbaik sistem pengurusan ganjaran kerja. Pertama, mempelbagai media penyampaian maklumat pampasan kepada pekerja. Sebagai contoh, maklumat pampasan disiarkan dalam hompej organisasi agar pekerja dapat membaca dan bertanya jika mereka tidak faham kelayakan ganjaran yang ditentukan oleh organisasi. Kedua, menganjur kursus-kursus mengenai sistem ganjaran kepada pengurus. Sebagai contoh, kurikulum dan kaedah mengendalikan latihan perlu dikemaskini supaya pengurus dapat memahami polisi dan prosedur terkini bagi mengurus ganjaran kerja, serta mereka juga patut didedahkan dengan kemahiran manusia dan teknik penyelesaian masalah agar dapat menggunakan kaedah layanan yang berhikmah dalam menangani aduan dan tuntutan pekerja.

Ketiga, polisi pengambilan pekerja perlu mengutamakan pengambilan pekerja yang kreatif dan inovasi. Sebagai contoh, organisasi perlu mengutamakan pengambilan individu yang berpengetahuan dan pengalaman kerja daripada individu yang baru bergraduat daripada institusi pengajian tinggi untuk mengisi jawatan penting dalam organisasi. Pengambilan individu sedemikian dapat membantu organisasi mereka bentuk kriteria penetapan ganjaran yang kreatif (seperti, penetapan jenis, tahap atau/dan amaun ganjaran berdasarkan sifat kerja, merit dan keperluan individu yang berlainan bagi menarik, mengekal dan mendorong pekerja menjayakan matlamat dan strategi organisasi), dan melaksanakan garis panduan pembahagian ganjaran yang lebih efisien (seperti, kurang karenah birokrasi dalam membuat keputusan tentang tuntutan kerja lebih masa, kerja rasmi luar pejabat, kemudahan rawatan kesihatan, pinjaman dan persaraan). Dengan mengambil kira cadangan ini, ia dapat mendorong pekerja menghormati dan menyokong pelaksanaan sistem ganjaran organisasi.

\section{Limitasi}

Kesimpulan yang dibuat berdasarkan dapatan kajian ini perlu mengambil kira batasan kerangka konseptual dan metodologi kajian. Pertama, kaedah keratan rentas yang digunakan dalam kajian ini tidak dapat mengesan isu-

IJMS 17 (1), 203-223 (2010) 
isu pembangunan atau/dan perhubungan antara pemboleh ubah yang lebih khusus. Sebagai contoh, kajian ini tidak mengetengahkan perhubungan antara indikator khusus bagi pemboleh ubah tidak bersandar (seperti, komunikasi tentang ganjaran kewangan dan faedah menggunakan teknologi), pemboleh ubah penyederhanaan (seperti, keadilan prosedur ganjaran kewangan dan faedah) dan pemboleh ubah bersandar (seperti, prestasi kerja bagi kumpulan pengurusan dan sokongan). Kedua, keputusan analisis regresi berganda hanya menfokuskan kepada penerangan tentang varian tahap prestasi berdasarkan persamaan regresi (Tabachnick \& Fidell, 2001), tetapi masih banyak lagi faktor-faktor lain yang penting (seperti, ciri-ciri organisasi dan demografi responden) tidak dihuraikan dalam kajian ini. Faktor-faktor ini perlu dimasukkan dalam analisis regresi bagi mengenal pasti sifat perhubungan sebab-akibat antara pemboleh ubah dan menganggarkan darjah kekuatan perhubungan antara pemboleh ubah tersebut. Ketiga, kebanyakan responden kajian ini berketurunan Melayu dan persepsi kaum ini mungkin lebih banyak mempengaruhi dapatan kajian ini. Keempat, kajian ini menggunakan teknik pensampelan mudah bagi mengumpul data daripada pekerja tempatan yang berkhidmat di sebuah organisasi. Akhir sekali, dapatan kajian ini hanya mencerminkan sifat interaksi di antara pemboleh ubah-pemboleh ubah kajian umum. Batasan-batasan ini boleh mengurangkan keupayaan dapatan kajian ini untuk digeneralisasikan kepada pelbagai latar organisasi yang berlainan.

\section{Arah Tuju Kajian Akan Datang}

Kekurangan yang terdapat dalam kajian ini perlu dijadikan sebagai panduan dalam memperkukuhkan kaedah penyelidikan dan kerangka teori sistem ganjaran pada masa akan datang. Pertama, elemen-elemen yang berkaitan dengan sistem komunikasi saraan, teori keadilan organisasi, dan sikap dan tingkah laku individu perlu ditambah dalam kerangka konseptual supaya ia dapat menghasilkan kesimpulan kajian yang lebih mantap. Kedua, faktor-faktor demografi (seperti, jantina, umur, kelulusan, jawatan, gaji, jabatan dan institusi) dan organisasi (seperti, jenis dan jabatan) perlu - dimasukkan dalam kerangka konseptual kajian bagi membina kesimpulan kajian yang lebih meyakinkan. Ketiga, kekurangan yang terdapat dalam kaedah keratan rentas boleh diatasi melalui penggabungan kaedah kajian berturutan (longitudinal study) bagi menghasilkan kesimpulan kajian yang mampu mengambilkira perkara-perkara yang lebih dinamik dalam sampel data.

Keempat, sebagai lanjutan daripada keadilan prosedur, literatur sistem ganjaran mendedahkan bahawa keadilan distributif merupakan satu komponen keadilan organisasi yang boleh mempengaruhi keberkesanan

218 IJMS 17 (1), 203-223 (2010) 


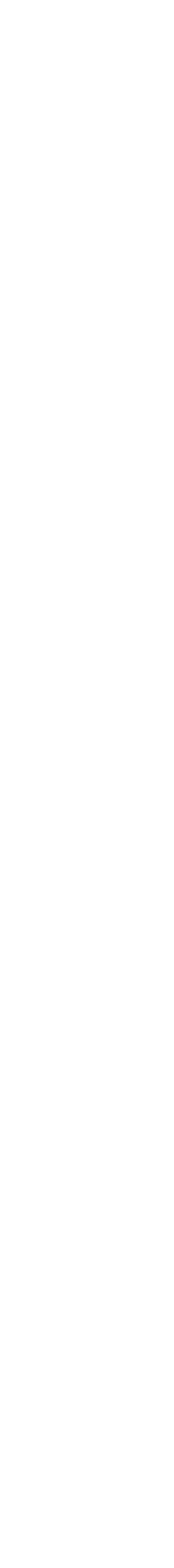

sistem ganjaran organisasi (deCarufel, 1986; Greenberg, 1996; Sweeney \& McFarlin, 1993). Sebagai contoh, seseorang pekerja yang merasakan bahawa jenis, tahap atau/dan amaun ganjaran yang diterima adalah setimpal dengan sumbangan atau beban kerjanya boleh mendorong beliau untuk menambahbaik sikap dan tingkah laku (contohnya, kepuasan, komitmen, dan etika) (Adams, 1963 \& 1965; Milkovich \& Newman, 2008). Sekiranya keadilan distributif digunakan sebagai pemboleh ubah penyederhana dalam kerangka teori kajian akan datang ia boleh menghasilkan kesimpulan kajian yang lebih baik.

Akhir sekali, literatur pengurusan saraan menerangkan bahawa sikap dan tingkah laku individu boleh diterjemahkan dalam beberapa aspek iaitu komitmen kerja, prestasi kerja, keinginan untuk berpindah dan etika kerja (Greenberg, 2003; Milkovich \& Newman, 2008; Sweeney \& McFarlin, 1993). Sekiranya aspek-aspek ini dimasukkan dalam analisis, ia akan menunjukkan dengan jelas aspek manakah yang lebih kuat dipengaruhi oleh perhubungan antara komunikasi mengenai sistem saraan dan keadilan prosedur. Cadangan-cadangan yang dibincangkan di atas perlu diberi perhatian untuk lebih memantapkan lagi kajian yang akan datang.

\section{Kesimpulan}

Dapatan kajian ini mengesahkan bahawa keadilan prosedur hanya bertindak sebagai pemboleh ubah penyederhana separa dalam perhubungan di antara amalan komunikasi dalam sistem ganjaran dan prestasi kerja di organisasi kajian. Oleh itu, kajian akan datang mengesyorkan bahawa keadilan prosedur perlu dijadikan sebagai satu elemen penting dalam komunikasi sistem ganjaran. Kewujudan rasa adil dalam diri pekerja terhadap amalan berkomunikasi sistem ganjaran akan mendorong pekerja untuk meningkatkan sikap dan tingkah laku yang positif (seperti prestasi kerja, prestasi kerja dan komitmen kerja). Pekerja yang mempunyai sikap dan tingkah laku yang positif akan dapat membantu mencapai misi dan wawasan organisasi serta jabatan sumber manusia.

\section{Rujukan}

Adams, J.S. (1963). Towards an understanding of inequity. Journal of Abnormal and Social Psychology, 67, 422-436.

Adams, J.S. (1965). Inequity in social exchange. In L. Berkowitz (Eds.), Advances in Experiments Social Psychology, 2, 267-299. New York: Academic Press.

IJMS 17 (1), 203-223 (2010) 
Aiken, L.S., West, S.G., \& Reno, R.R. (1991). Multiple regression: Testing and interpreting interactions. Nesbury Park, California: SAGE Publications.

Anthony, W.P., Perrewe, P.L., \& Kacmar, K.M. (1996). Strategic human resource management. New York: Harcourt Brace \& Company.

Armstrong, M., \& Murlis, H. (1994). Reward management: A handbook of remuneration strategy and practice. London: Kogan Page, London.

Azman Ismail, Abdul Fatah Ismail, \& Mohd Noor Mohd Shariff. (2007). Perhubungan antara sistem komunikasi pampasan dan kepuasan kerja: Adakah keadilan prosedur memainkan peranan bersyarat? International Journal of Management Studies, 14 (1), 2007, 121-147.

Balkin, D., \& Gomez-Mejia, L.R. (1990). Matching compensation and organizational strategies. Strategic Management Journal II, 153-169.

Bryne, B.M. (1998). Structural equation modelling with LISREL, PRELIS, and SIMPLIS: Basic concepts, applications, and programming. New Jersey: Lawrence Erlbaum Associates.

Cascio, W.F. (1995). Managing human resources. New York: McGraw-Hill.

Chang, P.L., \& Chen, W.L. (2002). The effect of human resource management practices on firm performance: Empirical evidence from high-tech firms in Taiwan. International Journal of Management, 19(4), 622-630.

Cohen, J., \& Cohen, P. (1983). Applied multiple regression/correlation analysis for the behavioural sciences. Hillsdale, New Jersey: Erlbaum.

Cohen-Charash, Y., \& Spector, P.E. (2001). The role of justice in organization: A meta-analysis. Organizational Behavior and Human Decision Processes, 86, 278-324.

Cooper, C., Dyck, B., \& Frohlich, N. (1992). Improving the effectiveness of gainsharing: The role of fairness and participation. Administrative Science Quarterly, 37, 471-490.

Cropanzano, R., Byrne, Z. S., Bobocel, D. R., \& Rupp, D. R. (2001). Moral virtues, fairness heuristics, social entities, and other denizens of organizational justice. Journal of Vocational Behavior, 58, 164-209.

Cropanzano, R., \& Greenberg, J. (1997). Progress in organizational justice: Tunelling through the maze. In C.L. Cooper, \& I. Robertson (Eds.), International Review of Industrial and Organizational Psychology, 12, 317371. New York: John Wiley \& Sons.

Cross, W. (1995). Encylopedia dictionary of business terms. Engleewood Cliffs, New Jersey: Prentice Hall.

deCarufel, A. (1986). Pay secrecy, social comparison, and relative deprivation in organizations. In J.M. Olson, C.P. Herman, \& M.P. Zanna (Eds.), Relative Deprivation and Social Symposium, 4, 181-199. Hillsdale, New Jersey: Lawrence Erlbaum.

Fitzgerald, L.R. (2000). Culture and compensation. In L.A. Berger, \& D.R. Berger (Eds.), The Compensation Handbook: A State-of-the-Art Guide to Compensation Strategy and Design, 531-540. New York: McGraw-Hill. 
Flannery, T.P., Hofrichter, D.A., \& Platten, P.E. (1996). People, performance, and pay: Dynamic compensation for changing organizations. New York: The Free Press.

Folger, R., \& Konovsky, M.A. (1989). Effects of procedural and distributive justice on reactions to pay raise decisions. Academy of Management Journal, 32, 115-130.

Greenberg, J. (1987a). Reactions to procedural injustice in payment distributions: Do the means justify the ends? Journal of Applied Psychology, 72, 55-61.

Greenberg, J. (1987b). Using diaries to promote procedural justice in performance appraisals. Social Justice Research, 1, 219-234.

Greenberg, J. (1996). The quest for justice on the job: Essays and experiments. Thousand Oaks, California: Sage.

Greenberg, J. (2003). Creating unfairness by mandating fair procedures: The hidden words of a pay-for-performance plan. Human Resource Management Review, 13, 41-57.

Guthrie, J.P. (2000). High involvement work practices, turnover, and productivity: Evidence from New Zealand. Academy of Management Journal, 44(1), 180-190.

Hair, J.F., Anderson, R.E., Tatham, R.L., \& Black, W.C. (1998). Multivariate data analysis. New Jersey: Prentice-Hall.

Henderson, R.I. (2007). Compensation management in a knowledge based-world. New Jersey: Prentice-Hall.

Heneman, H.G., \& Schwab, D.P. (1985). Pay satisfaction multidimensional nature and measurement. International Journal of Psychology, 20, 129141.

Hewitt Associates. (1991). Total compensation management: Reward management strategies for the 1990s. Oxford: Blackwell.

Jaccard, J., \& Wan,, C.K. (1996). LISREL approaches to interaction effects in multiple regression, 114. Thousand Oaks, California: Sage Publications.

Jaccard, J., Turrisi, R., \& Wan, C.K. (1990). Interaction effects in multiple regression. Newsbury Park, California: Sage.

Jones, F.F., Scarpello, V., \& Bergman, T. (1999). Pay procedures - what makes them fair? Journal of Occupational and Organization Psychology, 72(2), 129-145.

Kleinbaum, , D.G., Kupper, L.L., \& Muller, K.F. (1988). Applied regression analysis and other multivariable methods. Boston, Mass: PWS-Kent Publication.

Konovsky, M.A., \& Pugh, S.D. (1994). Citizenship behaviour and social exchange. Academy of Management Journal, 37, 656-699.

Lawler, E.E. (1981). Pay and organizational development. Reading, Mass.: Addison-Wesley. 
Lawler, E.E. (1982). Strategies for improving the quality of work life. American Psychologist, 37, 486-493.

Lawler, E.E. (1984). The strategic design of reward systems. In C.J. Fombrun, N. Tichy, \& M. Devanna (Eds.), Strategic Human Resource Management, 127-147. New York: Wiley.

Lawler, E.E. (1990). Strategic pay: Alligning organizational strategies and pay systems. San Francisco: Jossey-Bass.

Lawler, E.E., \& Hall, D.T. (1970). Relationship of job characteristics to job involvement, satisfaction and intrinsic motivation. Journal of Applied Psychology, 54, 305-312.

Leedy, P.D., \& Ormrod, J.E. (2005). Practical research: Planning and design ( $8^{\text {th }}$ ed.). Upper Saddle River, New Jesrsey: Pearson.

Leventhal, G.S. (1976). Fairness in social relationships. In J.T. Spence, \& R.C. Carson (Eds.), Contemporary Topics in Social Psychology, 211-240. Morristown, New Jersey: General Learning Press.

Lind, E.A., \& Tyler, T.R. (1988). The social psychology of procedural justice. New York: Plenum.

Mamman, A., \& Sulaiman, M. (1996). Managerial attitudes to pay system in the Malaysian public sector. Malaysian Management Review, 31(1), 29-43.

Martin, J.E., \& Lee, R.T. (Autumn 1992). Pay knowledge and referents in a tiered-employment setting. Industrial Relations (Canadian), 47(4), 54671.

Maurer, J.G., Shulman, J.M., Ruwe, M.C., \& Becherer, R.G. (1995). Encylopedia of business. New York: Gale Research.

Miceli, M.P., \& Lane, M.C. (1991). Antecedents of pay satisfaction: A review and extension. Research in Personnel Resources Management, 9, 235-309.

Milkovich, G.T., \& Newman, J.M. (2008). Compensation. Boston: Irwin McGraw-Hill.

Moorman, R.H. (1991). Relationship between organizational justice and organizational citizenship behaviors: Do fairness perceptions influence employee citizenship? Journal of Applied Psychology, 76, 845855.

Nunally, J.C., \& Bernstein, I.H. (1994). Psychometric theory. New York: McGraw- Hill.

Peterson, R.A. (2000). A meta-analysis of variance accounted for and factor loadings in exploratory factor analysis. Marketing Letters, 11 (3), 261275.

Pettijohn, C.E., Pettijohn, L.S., \& d'Amico, M. (2001). Charateristics of performance appraisals and their impact on sales force satisfaction. Human Resource Development Quarterly, 12(2), 127-146.

Rajkumar, K. (1996). Paying for performance: Designing effective compensation strategies. Malaysia: Pelanduk Publications.

222 IJMS 17 (1), 203-223 (2010) 
Reagan, J. (2000). Toward a set of standards for the use of factor analysis in the Journal of Broadcasting \& Electronic Media. Journal of Broadcasting \& Electronic Media, 44(2), 324-328.

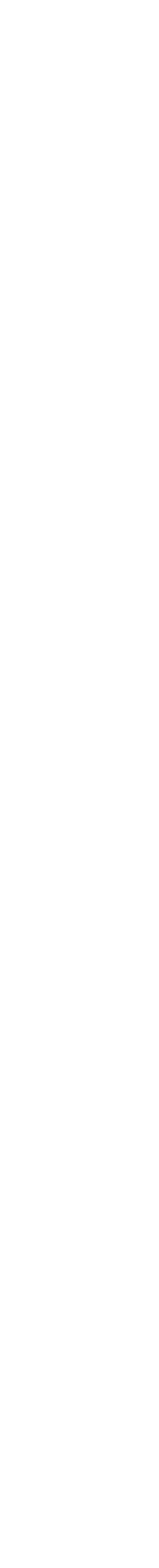

Robbins, S.P., \& Coultar, M. (2005). Management. Upper Saddle River, New Jersey: Pearson Prentice Hall

Robbins, T.L., Summers, T.P., Miller, J.L., \& Hendrix, W.H. (2000). Short research note using the group-value model to explain the role of noninstrumental justice in distinguishing the effects of distributive and procedural justice. Journal of Occupational and Organizational Psychology, 73, 511-518.

Sekaran, U. (2000). Research methods for business: A skill building approach. New York: John Wiley \& Sons.

Schaubroeck, J., May, D.R., \& Brown, F.W. (1994). Procedural justice explanations and employee reactions to economic hardship: A field experiment. Journal of Applied Psychology, 79, 455-460.

Snell, B. (2002). Management competing in the new era. Boston; McGraw-Hill Irwin.

Sweeney, P.D., \& McFarlin, D.B. (1993). Workers' evaluation of the "ends" and the "means": An examination of four models of distributive and procedural justice. Organizational Behavior and Human Decision Processes, 55, 23-49.

Tabachnick, B.G., \& Fidell, L.S. (2001). Using multivariate statistics. Sydney: Allyn \& Bacon.

Thibault, J., \& Walker, L. (1978). A theory of procedure. California Law Review, $66,541-566$.

Van Maanen, J. (1983). Qualitative methodology. Beverly Hills, CA: Sage.

Wallace, M.J., \& Fay, C.H. (1988). Compensation theory and practice. Massachusetts: PWS-Kent Publishing.

Warner, M. (1997). The concise international encylopedia of business $\mathcal{E}$ management. London: International Thompson Business Press.

Williams, M.L. (1995). Antecedents of employee benefit level satisfaction: A test of a model. Journal of Management, 21(6), 1097-1128.

Wright, L.L. (1996). Qualitative international management research. In B.J. Punnett, \& O. Shenkar (Eds.), Handbook for International Management Research, 63-81. Oxford, UK: Blackwell Publishers.

Zenger, T. (1992). Why do employers only reward extreme performance? Examining the relationships among performance, pay, and turnover. Administrative Science Quarterly, 37, 198-219. 